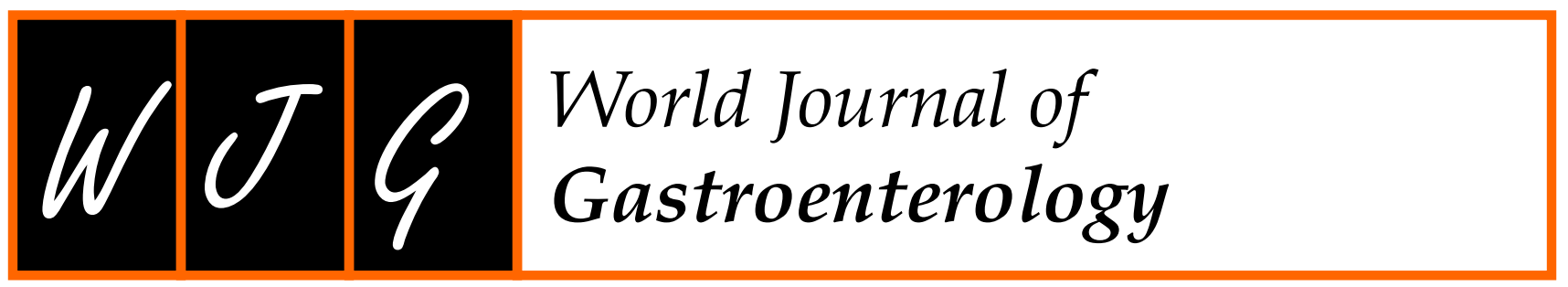

\title{
Positron-emission tomography for hepatocellular carcinoma: Current status and future prospects
}

\author{
Ren-Cai Lu, Bo She, Wen-Tao Gao, Yun-Hai Ji, Dong-Dong Xu, Quan-Shi Wang, Shao-Bo Wang
}

ORCID number: Ren-Cai Lu (0000-0002-0624-1310); Bo She (0000-0001-9769-4675); Wen-Tao Gao (0000-0002-3347-884X); YunHai Ji (0000-0002-6315-5320); DongDong Xu (0000-0002-1426-7641);

Quan-Shi Wang

(0000-0001-8878-9496); Shao-Bo

Wang (0000-0002-2745-522X).

Author contributions: Lu RC wrote the manuscript; She B, Gao WT, Ji $\mathrm{YH}, \mathrm{Xu} \mathrm{DD}$, Wang QS, and Wang SB helped to search the literature; Wang SB and Wang QS critically revised the manuscript and approved the final version of the article to be published.

Supported by the National Natural Science Foundation of China, No. 81760306; and the Basic Research on Application of Joint Special Funding of Science and

Technology Department of Yunnan Province-Kunming Medical University, No. 2018FE001(-291).

Conflict-of-interest statement: All the authors have no conflict of interest related to the manuscript.

Open-Access: This article is an open-access article which was selected by an in-house editor and fully peer-reviewed by external reviewers. It is distributed in accordance with the Creative Commons Attribution Non Commercial (CC BY-NC 4.0) license, which permits others to distribute, remix, adapt, build upon this work non-commercially, and license their derivative works on different terms, provided the original work is properly cited and the use is non-commercial. See: http:/ / creativecommons.org/licen
Ren-Cai Lu, Bo She, Wen-Tao Gao, Yun-Hai Ji, Dong-Dong Xu, Shao-Bo Wang, PET-CT Center, the First People's Hospital of Yunnan Province, Kunming 650032, Yunnan Province, China

Quan-Shi Wang, Nanfang PET Center, Nanfang Hospital, Southern Medical University, Guangzhou 510515, Guangdong Province, China

Shao-Bo Wang, Yunnan Key Laboratory of Primate Biomedical Research, Institute of Primate Translational Medicine, Kunming University of Science and Technology, Kunming 650093, Yunnan Province, China

Corresponding author: Shao-Bo Wang, MD, PhD, Associate Professor, PET-CT Center, the First People's Hospital of Yunnan Province, 157 Jinbi Road, Kunming 650032, Yunnan Province, China. wshbo98@126.com

Telephone: $+86-871-63614503$

Fax: +86-871-63614503

\section{Abstract}

Hepatocellular carcinoma (HCC) is one of the leading causes of cancer mortality worldwide. Various imaging modalities provide important information about HCC for its clinical management. Since positron-emission tomography (PET) or PET-computed tomography was introduced to the oncologic setting, it has played crucial roles in detecting, distinguishing, accurately staging, and evaluating local, residual, and recurrent HCC. PET imaging visualizes tissue metabolic information that is closely associated with treatment. Dynamic PET imaging and dual-tracer have emerged as complementary techniques that aid in various aspects of HCC diagnosis. The advent of new radiotracers and the development of immuno-PET and PET-magnetic resonance imaging have improved the ability to detect lesions and have made great progress in treatment surveillance. The current PET diagnostic capabilities for HCC and the supplementary techniques are reviewed herein.

Key words: Hepatocellular carcinoma; Positron-emission tomography; Radiotracer; Immuno-positron emission tomography

CThe Author(s) 2019. Published by Baishideng Publishing Group Inc. All rights reserved.

Core tip: Positron-emission tomography (PET) is an effective and noninvasive modality for visualizing hepatocellular carcinoma (HCC). This paper reviews the clinical utility of PET for HCC, including the detection of intrahepatic or extrahepatic lesions, differential diagnosis, prediction of differentiation and prognosis, and evaluation of therapeutic 
ses/by-nc/4.0/

Manuscript source: Invited manuscript

Received: April 12, 2019

Peer-review started: April 12, 2019

First decision: May 16, 2019

Revised: June 30, 2019

Accepted: July 19, 2019

Article in press: July 19, 2019

Published online: August 28, 2019

P-Reviewer: Aykan NF, Boin IFSF, Boteon YL, Kahraman A, Pompili M, Rodríguez-Perálvarez M, Sandhu DS

S-Editor: Yan JP

L-Editor: Wang TQ

E-Editor: Zhang YL

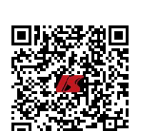

response. Complementary technologies, such as dynamic blood flow and dual-phase and dual-tracer PET imaging, are also mentioned. Novel radiotracers and immuno-PET have shown great potential for PET imaging and have become the focus of current research, which may enhance the diagnostic capability of PET for HCC. An overview of the current PET diagnostic status of HCC is reviewed.

Citation: Lu RC, She B, Gao WT, Ji YH, Xu DD, Wang QS, Wang SB. Positron-emission tomography for hepatocellular carcinoma: Current status and future prospects. World $J$ Gastroenterol 2019; 25(32): 4682-4695

URL: https://www.wjgnet.com/1007-9327/full/v25/i32/4682.htm

DOI: https://dx.doi.org/10.3748/wjg.v25.i32.4682

\section{INTRODUCTION}

Hepatocellular carcinoma (HCC) is the second most common cause of death from cancer worldwide, with more than 740000 deaths each year ${ }^{[1]}$. Although modern management methodologies for HCC patients, such as surgical resection and comprehensive treatment (radiotherapy, chemotherapy, immunotherapy, interventional therapy, or combined) have been developed, the overall survival (OS) rate remains low. Liver transplantation (LT), partial liver resection, and ablation remain the main therapeutic tools for HCC and have a high rate of complete response. However, most patients are diagnosed at an advanced stage and are complicated with multiple lesions and liver cirrhosis; no more than $40 \%$ of HCC patients have the opportunity to undergo surgery ${ }^{[2]}$.

Careful selection of candidates is vital for improving treatment outcomes. Evaluation of HCC should be referred to multidisciplinary teams that include surgeons, oncologists, hepatologists, and radiologists. Serum alpha-fetoprotein (AFP) levels have been widely used to diagnose HCC in the early stage; however, this test is limited due to its low sensitivity of approximately $25 \%^{[3]}$. Contrast-enhanced ultrasound (CEUS) imaging is useful for HCC diagnosis only when the tumor sites are identified by B-mode US ${ }^{[4]}$. Contrast-enhanced computed tomography (CECT) or magnetic resonance imaging (MRI) are also available for HCC screening, and each has its own advantages, such as multiphase enhancement characteristics and easy acquisition, but their accuracy may be lower when lesions are smaller than $2 \mathrm{~cm}^{[5-7]}$. Digital angiography is another examination method that can diagnose HCC, but it is invasive and is usually only performed when transarterial treatment is necessary ${ }^{[4]}$. Although these examinations are well utilized by surgeons for preoperative staging, they often show only a part of the body and detect morphologic changes that can occur quite slowly in HCC. In addition, these traditional examination techniques cannot detect recurrent, residual, or metastatic lesions well.

Positron-emission tomography (PET) seems to be a more effective and noninvasive modality than traditional radiography techniques for scanning the whole body ${ }^{[8]}$. Although 2-deoxy-2- $\left({ }^{18} \mathrm{~F}\right)$ fluoro-D-glucose $\left({ }^{18} \mathrm{~F}-\mathrm{FDG}\right)$ PET has a low sensitivity, between $36 \%$ and $70 \%$, in detecting $\mathrm{HCC}^{[9-11]}$, the application of PET-CT for diagnosing HCC has made great progress in recent years. This review presents an overview of the current status and future prospects of PET for diagnosing HCC.

\section{RADIOTRACERS}

${ }^{18} \mathrm{~F}-\mathrm{FDG}$ is the most widely used radiotracer for PET-CT; ${ }^{18} \mathrm{~F}$ has a long half-life $(110$ min), the best imaging spatial resolution, and favorable nuclear and chemical properties ${ }^{[12]} .{ }^{18} \mathrm{~F}-\mathrm{FDG}$ is a radiolabeled glucose analog in which the positron emitter radioactive isotope ${ }^{18} \mathrm{~F}$ replaces the hydroxyl group at the $\mathrm{C} 2$ position in the glucose molecule. ${ }^{18} \mathrm{~F}-\mathrm{FDG}$ is transported across the cell membrane by glucose transporters (GLUTs); in HCC, GLUT1, GLUT3, and, more recently, GLUT12, have been associated with the transport of this radiopharmaceutical into cancer cells. Multidrug resistance (MDR) is the ability of tumor cells to become resistant to different drugs and represents a major barrier to successful treatments. The overexpression of MDR proteins is thought to be a major obstacle to successful chemotherapy in various cancer types, including HCC. Studies have shown that cells that present increased MDR protein expression exhibit lower ${ }^{18} \mathrm{~F}-\mathrm{FDG}$ accumulation ${ }^{[13]}$. In intracellular terms, 
${ }^{18} \mathrm{~F}-\mathrm{FDG}$ is phosphorylated by hexokinase II to ${ }^{18} \mathrm{~F}$-FDG-6-phosphate, which cannot be metabolized in the glycolytic pathway and accumulates in metabolically active cells.

${ }^{18} \mathrm{~F}$-labeled amino acids and peptides have potential application value for PET imaging in HCC or other tumors ${ }^{[14-18]}$. Sun et al ${ }^{[19]}$ synthesized $N-\left(2-{ }^{18} \mathrm{~F}\right.$-fluoropropionyl)-L-glutamate $\left({ }^{18} \mathrm{~F}-\mathrm{FPGLU}\right)$, and the radiochemical purity was higher than $95 \%$, with a specific activity of 30-40 GBq/ $\mu$ mol. Although the novel tracer showed good tumor-to-background contrast and good stability in vitro, ${ }^{18} \mathrm{~F}$-FPGLU was metabolically unstable in plasma, urine, and tumor tissues ${ }^{[20]}$.

${ }^{18} \mathrm{~F}$-fluorocholine is another radiotracer used in PET imaging that radiolabels phosphocholine, the major metabolite in cancer cells that is responsible for choline uptake and has a steady distribution that is available within $10 \mathrm{~min}$, demonstrating high sensitivities of $89 \%$ for hepatic HCC and 100\% for extrahepatic HCC ${ }^{[21,22]}$. Although the ${ }^{18} \mathrm{~F}$-labeled metabolites are not able to be synthesized in every medical center, they still perform better than other radiolabels in diagnosing HCC.

Other promising radiopharmaceuticals currently used in PET-CT include ${ }^{11} \mathrm{C}$ labeled acetate $\left({ }^{11} \mathrm{C}\right.$-ACT) and ${ }^{11} \mathrm{C}$-labeled choline $\left({ }^{11} \mathrm{C}-\mathrm{CHOL}\right){ }^{[23]} \cdot{ }^{11} \mathrm{C}$-ACT is a radiopharmaceutical that is widely used in the imaging of HCC, primary brain tumors, carcinoid tumors, prostate adenocarcinoma, and transitional cell carcinoma ${ }^{[24]}$. As a substrate, ${ }^{11} \mathrm{C}$-ACT enters the Krebs cycle for $\beta$-oxidation in fatty acid synthase (FASN) and cholesterol synthesis. Fatty acid synthesis is thought to be the key factor for the uptake of ${ }^{11} \mathrm{C}$-ACT by liver neoplasms. Increased ${ }^{11} \mathrm{C}$-ACT uptake is often considered to reflect the increased de novo lipogenesis rate and to be associated with increased FASN expression ${ }^{[25,26]}$. Unlike ${ }^{18} \mathrm{~F}-\mathrm{FDG},{ }^{11} \mathrm{C}-\mathrm{ACT}$ mainly reflects the growth activity of tumor cells and may provide a complementary role to conventional radiotracers $^{[27]}$.

${ }^{11} \mathrm{C}-\mathrm{CHOL}$ is a precursor for phospholipid synthesis of the cell membrane. ${ }^{11} \mathrm{C}$ CHOL has a high PET signal in liver tumor cells due to the increased activities of choline transporter and choline kinase. In addition, HCC foci gained a better tumorto-background contrast with $\mathrm{CHOL}^{[28,29]}$. Nevertheless, ${ }^{11} \mathrm{C}$ has a short half-life of approximately $20 \mathrm{~min}$, and the use of ${ }^{11} \mathrm{C}$-labeled tracers is limited based on access to an on-site cyclotron, whereas ${ }^{18} \mathrm{~F}$ has a longer half-life than ${ }^{11} \mathrm{C}^{[28]}$.

Another alternative tracer is the ${ }^{68} \mathrm{Ga}$-labeled 1,4,7,10-tetraazacyclododecane$1,4,7,10$-tetraacetic acid (DOTA) conjugate of serum albumin or peptides. With an appropriate physical half-life (68 $\mathrm{min})$ and good blood clearance, ${ }^{68} \mathrm{Ga}$-DOTA may be a potential radiotracer for use in imaging $\mathrm{HCC}^{[30,31]}$. Studies have shown that ${ }^{68} \mathrm{Ga}-$ DOTA has a higher sensitivity than ${ }^{18} \mathrm{~F}$-DOTA, as ${ }^{68} \mathrm{Ga}$-DOTA had a greater PET uptake than ${ }^{18} \mathrm{~F}-\mathrm{FDG}$ in low-grade neuroendocrine tumors ${ }^{[29]}$. Gao et al ${ }^{[32]}$ demonstrated that ${ }^{68} \mathrm{Ga}$-asparagine-glycine-arginine uptake was higher than ${ }^{18} \mathrm{~F}-\mathrm{FDG}$ uptake for imaging well-differentiated HCC xenografts. However, limited data using ${ }^{68} \mathrm{Ga}$ for HCC are now emerging, and its potential clinical utility is unclear.

${ }^{64} \mathrm{Cu}$ radionuclide has a half-life of $12.7 \mathrm{~h}$ and is a novel biomarker for molecular imaging of $\mathrm{HCC} .{ }^{64} \mathrm{CuCl}_{2}$ PET-CT was able to detect early intracranial and other extrahepatic metastases located in areas with low physiological uptake, such as musculoskeletal tissues, which is important for determining the stage and prognosis of patients with HCC. This radionucleotide also plays an important role in treatment method selection. However, ${ }^{64} \mathrm{Cu}$ has an abundant physiological distribution in the liver, which will decrease the tumor-to-background contrast and make the lesions unrecognizable, which will limit its value of evaluation for HCC. Furthermore, altered copper metabolism is expected to be a target for radionuclide therapy of HCC using therapeutic copper radionuclides ${ }^{[33]}$. Another promising radiotracer, ${ }^{89} \mathrm{Zr}$, will be reviewed in relation to immuno-PET in detail later in the article. The important findings about these radiotracers are summarized in Tables 1 and 2.

\section{${ }^{8} \mathrm{~F}$-FDG PET}

\section{Detection of intrahepatic or extrahepatic lesions}

Although HCC is the only solid tumor that can be diagnosed by the characteristics of "arterial phase hyperenhancement" and "washout" on CT or MRI after contrast medium injection ${ }^{[5]}$, there are still limitations in the biology of HCC that CT or MRI cannot show but that can be presented by the metabolic information from PET-CT ${ }^{[34]}$; however, none of these examinations can present the local tumor extent or detect distant metastases in the same examination. ${ }^{18} \mathrm{~F}-\mathrm{FDG}$ PET-CT can also enhance the detection capacity for synchronous neoplasms in patients with HCC, which may be misdiagnosed as primary lesions or metastasis ${ }^{[3]}$.

${ }^{18} \mathrm{~F}-\mathrm{FDG}$ PET gives hepatologists complementary imaging details about primary HCC lesions and extrahepatic metastases, and this additional information is 
Table 1 Positron emission tomography for intrahepatic or extrahepatic hepatocellular carcinoma

\begin{tabular}{|c|c|c|c|c|c|c|c|c|c|c|c|}
\hline \multirow[b]{2}{*}{ Isotopes } & \multirow[b]{2}{*}{ Half-life } & \multirow[b]{2}{*}{$\begin{array}{l}\text { Radiotr- } \\
\text { acer }\end{array}$} & \multirow[b]{2}{*}{ Year } & \multirow[b]{2}{*}{$\begin{array}{l}\text { First } \\
\text { author }\end{array}$} & \multirow{2}{*}{$\begin{array}{l}\text { No. of } \\
\text { patients }\end{array}$} & \multirow{2}{*}{$\begin{array}{l}\text { Study } \\
\text { design }\end{array}$} & \multicolumn{2}{|c|}{ Intrahepatic } & \multicolumn{2}{|c|}{ Extrahepatic } & \multirow{2}{*}{$\begin{array}{l}\text { Related } \\
\text { notable } \\
\text { findings }\end{array}$} \\
\hline & & & & & & & $\begin{array}{l}\text { Sensiti- } \\
\text { vity }\end{array}$ & $\begin{array}{l}\text { Specifi- } \\
\text { city }\end{array}$ & $\begin{array}{l}\text { Sensiti- } \\
\text { vity }\end{array}$ & $\begin{array}{l}\text { Specifi- } \\
\text { city }\end{array}$ & \\
\hline \multirow[t]{4}{*}{${ }^{18} \mathrm{~F}$} & $110 \mathrm{~min}$ & ${ }^{18} \mathrm{~F}$-FDG & 2019 & Lee $e$ al $l^{[11]}$ & - & Review & $0.36-0.70$ & NA & NA & NA & \multirow{3}{*}{$\begin{array}{l}{ }^{18} \text { F-FDG } \\
\text { PET has } \\
\text { demonstr- } \\
\text { ated a } \\
\text { higher } \\
\text { sensitivity } \\
\text { for } \\
\text { detecting } \\
\text { extrahepa- } \\
\text { tic } \\
\text { metastasis } \\
\text { compared } \\
\text { to primary } \\
\text { HCC }\end{array}$} \\
\hline & & & 2012 & $\begin{array}{l}\text { Hossein } \\
\text { Jadvar }^{[29]}\end{array}$ & & Review & NA & 0.91 & NA & NA & \\
\hline & & & 2012 & Lin $e t a l^{[89]}$ & & $\begin{array}{l}\text { Meta- } \\
\text { analysis }\end{array}$ & NA & NA & 0.77 & 0.98 & \\
\hline & & ${ }^{18} \mathrm{~F}-\mathrm{FCH}$ & 2014 & $\begin{array}{l}\text { Bieze et } \\
a l^{[21]}\end{array}$ & 30 & $\begin{array}{l}\text { Prospective } \\
\text {; single- } \\
\text { center }\end{array}$ & 0.88 & 1.0 & 1.0 & 1.0 & $\begin{array}{l}{ }^{18} \mathrm{~F}-\mathrm{FCH} \\
\text { shows } \\
\text { additional } \\
\text { value in the } \\
\text { assessment } \\
\text { of intra- } \\
\text { and } \\
\text { extrahepa- } \\
\text { tic diseases }\end{array}$ \\
\hline \multirow[t]{2}{*}{${ }^{11} \mathrm{C}$} & $20 \mathrm{~min}$ & ${ }^{11} \mathrm{C}-\mathrm{ACT}$ & 2009 & $\begin{array}{l}\text { Hwang et } \\
a l^{[27]}\end{array}$ & 13 & Prospective & 0.83 & NA & 0.77 & NA & $\begin{array}{l}{ }^{11} \mathrm{C} \\
\text { increases } \\
\text { the } \\
\text { sensitivity } \\
\text { in the } \\
\text { detection } \\
\text { of HCC } \\
\text { lesions of } \\
\text { more than } \\
10 \mathrm{~mm}\end{array}$ \\
\hline & & ${ }^{11} \mathrm{C}-\mathrm{CHOL}$ & 2016 & $\begin{array}{l}\text { Castilla- } \\
\text { Lièvre et } \\
\text { al } l^{771]}\end{array}$ & 28 & $\begin{array}{l}\text { Prospective } \\
\text {; single- } \\
\text { center }\end{array}$ & 0.67 & NA & NA & NA & $\begin{array}{l}\text { Combining } \\
{ }^{18} \mathrm{~F}-\mathrm{FDG} \\
\text { with }{ }^{11} \mathrm{C}- \\
\mathrm{CHOL} \\
\text { could be } \\
\text { useful for } \\
\text { clinicians } \\
\text { in the } \\
\text { manage- } \\
\text { ment of } \\
\text { HCC } \\
\text { patients }\end{array}$ \\
\hline
\end{tabular}

HCC: Hepatocellular carcinoma; NA: Not available;

${ }^{18} \mathrm{~F}$-FDG: 2-deoxy-2- $\left({ }^{18} \mathrm{~F}\right)$ fluoro-D-glucose; ${ }^{18} \mathrm{~F}-\mathrm{FCH}:{ }^{18} \mathrm{~F}$-fluorocholine;

${ }^{11} \mathrm{C}$-ACT: $11 \mathrm{C}$-acetate; ${ }^{11} \mathrm{C}-\mathrm{CHOL}:{ }^{11} \mathrm{C}$-choline.

associated with treatment selection ${ }^{[36]}$. ${ }^{18} \mathrm{~F}-\mathrm{FDG}$ PET-CT is usually a complementary method for routine examinations because the accumulation of FDG in HCC varies. According to the current European Association for the Study of the Liver Clinical Practice Guidelines for the management of HCC, ${ }^{18} \mathrm{~F}-\mathrm{FDG}$ uptake was observed in less than $40 \%$ of HCC patients ${ }^{[37]}$. Studies have demonstrated that low ${ }^{18} \mathrm{~F}-\mathrm{FDG}$ uptake is correlated with high FDG-6-phosphatase activity, high expression of P-glycoprotein, and low expression of GLUT1 or GLUT2 in moderately and well-differentiated $\mathrm{HCC}^{[38]} .{ }^{18} \mathrm{~F}-\mathrm{FDG}$ is transported into cells and phosphorylated to FDG-6-phosphate, which is trapped within cells. However, high levels of FDG-6-phosphatase hydrolyzes FDG-6-phosphate to FDG, which is then transported outside the cells, and high expression of P-glycoprotein acts as an efflux pump to also transport FDG out of the cell, and low expression of GLUT1 or GLUT2 reduces the uptake of FDG. These reasons contribute to lower FDG accumulation in tumors ${ }^{[11,39,40]}$.

PET scanning has a high sensitivity for detecting extrahepatic metastases but a low sensitivity for primary $\mathrm{HCC}^{[4]}$. The reason is that normal liver tissue has a relatively high FDG uptake, which reduces the tumor-to-liver standardized uptake value (SUV) 
Table 2 Positron emission tomography in animal experiments of hepatocellular carcinoma

\begin{tabular}{|c|c|c|c|c|c|c|c|}
\hline Isotopes & Half-life & Radiotracer & Year & First author & Animal models & $\begin{array}{l}\text { Related notable } \\
\text { findings }\end{array}$ & Limitations \\
\hline \multirow[t]{3}{*}{${ }^{18} \mathrm{~F}$} & \multirow[t]{3}{*}{$110 \mathrm{~min}$} & \multirow[t]{3}{*}{${ }^{18} \mathrm{~F}-\mathrm{FPGLU}$} & \multirow[t]{3}{*}{2017} & \multirow[t]{3}{*}{ Sun et al ${ }^{[19]}$} & \multirow[t]{3}{*}{$\begin{array}{l}\text { Tumor-bearing } \\
\text { mice (HCC } \\
\text { SMCC-7721) }\end{array}$} & $\begin{array}{l}\text { Radiochemical } \\
\text { purity is higher } \\
\text { than } 95 \% \text { with a } \\
\text { specific activity of } \\
30-40 \mathrm{GBq} / \mu \mathrm{mol}\end{array}$ & \multirow[t]{3}{*}{$\begin{array}{l}\text { Unstable in } \\
\text { plasma, tumor, } \\
\text { and urine }\end{array}$} \\
\hline & & & & & & Stable in vitro & \\
\hline & & & & & & $\begin{array}{l}\text { High uptake and } \\
\text { retention in } \\
\text { tumor }\end{array}$ & \\
\hline \multirow[t]{2}{*}{${ }^{64} \mathrm{Cu}$} & \multirow[t]{2}{*}{$12.7 \mathrm{~h}$} & \multirow[t]{2}{*}{${ }^{64} \mathrm{CuCl}_{2}$} & \multirow[t]{2}{*}{2011} & \multirow[t]{2}{*}{ Lièvre $e t a l^{[71]}$} & \multirow{2}{*}{$\begin{array}{l}\text { Athymic mice } \\
\text { bearing } \\
\text { extrahepatic HCC } \\
\text { xenografts }\end{array}$} & $\begin{array}{l}\text { Increased }{ }^{64} \mathrm{Cu} \\
\text { radioactivity is } \\
\text { well visualized }\end{array}$ & \multirow{2}{*}{$\begin{array}{l}\text { Abundant } \\
\text { physiological } \\
\text { distribution in } \\
\text { liver }\end{array}$} \\
\hline & & & & & & $\begin{array}{l}\text { Useful for } \\
\text { detection of } \\
\text { intracranial HCC } \\
\text { metastasis }\end{array}$ & \\
\hline \multirow[t]{2}{*}{${ }^{68} \mathrm{Ga}$} & \multirow[t]{2}{*}{$68 \mathrm{~min}$} & \multirow[t]{2}{*}{${ }^{68}$ Ga-NGR } & \multirow[t]{2}{*}{2017} & \multirow[t]{2}{*}{ Gao et $a l^{[32]}$} & \multirow[t]{2}{*}{$\begin{array}{l}\text { Tumor-bearing } \\
\text { mice (HCC } \\
\text { SMCC-7721) }\end{array}$} & $\begin{array}{l}{ }^{68} \text { Ga-NGR could } \\
\text { visualize CD13- } \\
\text { positive tumors }\end{array}$ & \multirow{2}{*}{$\begin{array}{l}\text { The uptake } \\
\text { performance of } \\
{ }^{68} \text { Ga-NGR for } \\
\text { poorly } \\
\text { differentiated } \\
\text { HCC needs } \\
\text { further } \\
\text { investigation }\end{array}$} \\
\hline & & & & & & $\begin{array}{l}{ }^{68} \text { Ga-NGR uptake } \\
\text { is significantly } \\
\text { higher than that } \\
\text { of } 18 \text { F-FDG in } \\
\text { well- } \\
\text { differentiated } \\
\text { HCC xenografts }\end{array}$ & \\
\hline \multirow[t]{8}{*}{${ }^{89} \mathrm{Zr}$} & \multirow[t]{8}{*}{$78.4 \mathrm{~h}$} & \multirow[t]{2}{*}{${ }^{89} \mathrm{Zr}-\mathrm{aGPC} 3$} & \multirow[t]{2}{*}{2014} & \multirow[t]{2}{*}{ Sham et al ${ }^{[79]}$} & \multirow[t]{2}{*}{$\begin{array}{l}\text { HepG2 tumor- } \\
\text { bearing mice }\end{array}$} & $\begin{array}{l}\text { Excellent } \\
\text { specificity }\end{array}$ & \multirow[b]{2}{*}{$\begin{array}{l}\text { Long half-life in } \\
\text { the blood, leading } \\
\text { to suboptimal } \\
\text { imaging } \\
\text { pharmacokinetics, } \\
\text { poorer tumor } \\
\text { penetration, and } \\
\text { increased } \\
\text { immunogenicity } \\
\text { due to relatively } \\
\text { large size and } \\
\text { intact Fc regions }\end{array}$} \\
\hline & & & & & & $\begin{array}{l}\text { Even smaller } \\
\text { tumors }(<1 \mathrm{~mm}) \\
\text { are able to be } \\
\text { identified }\end{array}$ & \\
\hline & & \multirow[t]{2}{*}{$\begin{array}{l}{ }^{89} \mathrm{Zr}-\mathrm{aGPC}- \\
\mathrm{F}\left(\mathrm{ab}^{\prime}\right) 2\end{array}$} & \multirow[t]{2}{*}{2014} & \multirow[t]{2}{*}{ Sham et al ${ }^{[80]}$} & \multirow[t]{2}{*}{$\begin{array}{l}\text { HepG2 tumor- } \\
\text { bearing mice }\end{array}$} & $\begin{array}{l}\text { Significantly } \\
\text { reduces blood } \\
\text { circulation time }\end{array}$ & \multirow{2}{*}{$\begin{array}{l}\text { Potential risk of } \\
\text { fragment } \\
\text { concentration in } \\
\text { the kidneys, } \\
\text { leading to organ } \\
\text { dysfunction }\end{array}$} \\
\hline & & & & & & $\begin{array}{l}\text { Lower } \\
\text { background liver } \\
\text { uptake allows for } \\
\text { early imaging }\end{array}$ & \\
\hline & & \multirow[t]{2}{*}{${ }^{89} \mathrm{Zr}$-DFO-1G12 } & \multirow[t]{2}{*}{2014} & \multirow[t]{2}{*}{ Yang et $a l^{[81]}$} & \multirow[t]{2}{*}{$\begin{array}{l}\text { HepG2 tumor- } \\
\text { bearing mice }\end{array}$} & $\begin{array}{l}\text { Specifically taken } \\
\text { up by GPC3- } \\
\text { positive HCC } \\
\text { xenografts } \\
\text { regardless of } \\
\text { GPC3 expression } \\
\text { levels }\end{array}$ & $\begin{array}{l}\text { This probe should } \\
\text { be further } \\
\text { validated using a } \\
\text { humanized anti- } \\
\text { GPC } 3 \text { antibody }\end{array}$ \\
\hline & & & & & & $\begin{array}{l}\text { High tumor-to- } \\
\text { liver ratio }\end{array}$ & \\
\hline & & $\begin{array}{l}{ }^{89} \text { Zr-Df-YY146- } \\
\text { ZW800 }\end{array}$ & 2016 & $\begin{array}{l}\text { Hernandez et } \\
a l^{[82]}\end{array}$ & $\begin{array}{l}\text { HepG2 tumor- } \\
\text { bearing mice }\end{array}$ & $\begin{array}{l}\text { Excellent CD146- } \\
\text { affinity, } \\
\text { specificity, and } \\
\text { stability }\end{array}$ & $\begin{array}{l}\text { Bone-displaying } \\
\text { PET signal is not } \\
\text { matched by NIRF }\end{array}$ \\
\hline & & & & & & $\begin{array}{l}\text { Both PET and } \\
\text { NIRF imaging are } \\
\text { achieved }\end{array}$ & \\
\hline
\end{tabular}

HCC: Hepatocellular carcinoma; PET: Positron emission tomography;

${ }^{18}$ F-FPGLU: N-(2- ${ }^{18}$ F-fluoropropionyl)-L-glutamate;

${ }^{68} \mathrm{Ga}-\mathrm{NGR}:{ }^{68} \mathrm{Ga}$-labeled asparagine-glycine-arginine;

${ }^{89} \mathrm{Zr-aGPC} 3:{ }^{89} \mathrm{Zr}$-anti glypican-3; ${ }^{89} \mathrm{Zr}$-aGPC3-F(ab')2: ${ }^{89} \mathrm{Zr}$-anti glypican-3-F(ab')2; ${ }^{89} \mathrm{Zr}-\mathrm{DFO}-1 \mathrm{G} 12:{ }^{89} \mathrm{Zr}-\mathrm{desferrioxamine-1G12;}{ }^{89} \mathrm{Zr-Df}-\mathrm{YY} 146-\mathrm{ZW} 800$ :

${ }^{89} \mathrm{Zr}$ - deferoxamine-YY146-ZW800; NIRF: Near-infrared fluorescence. 
ratio (TLR) and makes it difficult to visualize tumor lesions ${ }^{[2]}$. However, extrahepatic metastases usually have a low FDG uptake background to visualize. Based on the Barcelona Clinic Liver Cancer staging classification, patients with HCC have lymph node metastasis that usually indicates an advanced stage. Metastasis is a fairly common sequela in HCC, occurring in more than $50 \%$ of patients; most of these metastases frequently affect the lungs (18\%-53.8\%), lymph nodes $(26.7 \%-53 \%)$, and diaphragm and skeleton (5.8\%-38.5\% $)^{[43,44]}$. Among them, lymph node metastasis most frequently occurs, with an incidence of more than $50 \%$. Retroperitoneal lymph node metastasis is more frequent than porta hepatis lymph node metastasis ${ }^{[45]} .{ }^{18} \mathrm{~F}-\mathrm{FDG}$ PET-CT has a higher sensitivity to detect lymph node metastasis, which is a poor prognostic factor for $\mathrm{HCC}^{[29]}$.

In view of the potential value of PET-CT for extrahepatic lesions, PET-CT should be considered for initial HCC staging work-ups to formulate a plan for patients who are candidates for hepatic resection (HR) or $\mathrm{LT}^{[44]}$. Although CT, MRI, and bone scintigraphy are recommended for preoperative HCC staging, HCC metastasis to uncommon sites, such as the oral cavity, jaw, thyroid, and adrenal glands, may be detected only by ${ }^{18} \mathrm{~F}$-FDG PET-CT ${ }^{[3,46,47]}$ and easily missed by conventional CT and MRI. Overall, ${ }^{18} \mathrm{~F}-\mathrm{FDG}$ PET-CT has additional value for HCC staging.

\section{Differential diagnosis}

There are few studies on the differential diagnosis of HCC, and the utility of PET-CT for differential diagnosis is limited. Several case reports ${ }^{[48-50]}$ have shown that PET-CT is a useful tool to differentiate primary or secondary neoplasms, but these studies did not systematically summarize the signs of differential diagnosis from HCC. Malignant lesions may increase radiotracer uptake, and PET-CT is of value for the following reasons.

${ }^{18} \mathrm{~F}-\mathrm{FDG}$ PET-CT is very helpful to assess the malignant potential of hepatic lesions of unknown origin through simultaneous visualization of the liver and extrahepatic tissue and for further confirmation of a clinically suspected extrahepatic metastasis of known $\mathrm{HCC}^{[51]}$. ${ }^{18} \mathrm{~F}-\mathrm{FDG}$ PET-CT has the potential value to distinguish malignant thrombus from a bland thrombus of the portal vein in patients with HCC, which is of great clinical significance for determining the therapeutic approach, predicting survival, and assessing candidates for $\mathrm{LT}^{[52]}$. However, no studies have shown that PET-CT has higher value to diagnose bland thrombus than CT, MRI, or even fine needle biopsy. ${ }^{18} \mathrm{~F}$-FDG PET-CT may play an important role in differentiating malignant lymph metastasis from lymphoproliferative diseases ${ }^{[53]}$. However, there is no denying that these conclusions are drawn from case reports, and more evidence is needed to support these topics in further studies.

Additionally, there is a lack of literature to differentiate between HCC and intrahepatic cholangiocellular carcinoma using ${ }^{18} \mathrm{~F}$-FDG PET alone. Conventional CT and MRI, especially with contrast enhancement, are useful ${ }^{[54]}$, and developing new specific radiotracers can be a desirable alternative for enhancing the ability of differential diagnosis.

\section{Prediction of differentiation and prognosis}

${ }^{18}$ F-FDG PET is expected to describe tumor aggressiveness of HCC, and high accumulation of FDG is associated with biological malignancy ${ }^{[5]}$. Moderately and welldifferentiated HCC may show low glucose metabolism, whereas ${ }^{18} \mathrm{~F}-\mathrm{FDG}$ uptake by poorly differentiated HCC may be visualized as a hot spot on a PET scan ${ }^{[56]}$. The main reason is the high FDG-6-phosphatase activity in well-differentiated HCC, which resembles normal liver tissue, thus reducing FDG accumulation in the lesions ${ }^{[3,39]}$.

Pretreatment ${ }^{18} \mathrm{~F}$-FDG PET has incremental prognostic value for OS in both intrahepatic and extrahepatic diseases. In addition, for patients with intermediate-toadvanced stage HCC confined to the liver, TLR is an independent prognostic factor for progression-free survival (PFS) and OS ${ }^{[7,58]}$. A TLR of 1.2 or more has a statistically significant association with microvascular invasion (MVI) ${ }^{[5,60]}$. Patients with MVI and those with poorly differentiated grade show significantly higher recurrence rates ${ }^{[5]}$. Kobayashi et al ${ }^{[61]}$ suggested that the combination of an $\mathrm{SUV}_{\max }$ of 3.2 or greater and an AFP-L3 level of $19 \%$ or greater are useful for selecting small numbers of HCC patients for HR or LT.

${ }^{18} \mathrm{~F}$-FDG PET-CT can also predict the prognosis of patients with HCC after treatment. ${ }^{18} \mathrm{~F}-\mathrm{FDG}$ PET-CT is sensitive to detecting recurrent extrahepatic lesions of HCC after hepatectomy or radiofrequency ablation, which has a diagnostic sensitivity of $90-100 \%$ for recurrent or metastatic hepatic tumors ${ }^{[2]} .{ }^{18} \mathrm{~F}-\mathrm{FDG}$ PET-CT is a valid prognostic tool in patients with HCC who are candidates for orthotopic liver transplantation (OLT); positivity on PET is the only factor related to early recurrence of HCC after OLT, and the combination of findings on PET and the AFP levels provides even more decisive results ${ }^{[63]}$. 
Evaluation of therapeutic response

${ }^{18} \mathrm{~F}-\mathrm{FDG}$ uptake is closely related to therapeutic response in HCC and can offer additional information on the risk of HCC recurrence after surgery. PET status may be a significant and independent risk factor for posttreatment recurrence of HCC after $\mathrm{LT}^{[55]}$. ${ }^{18} \mathrm{~F}$-FDG PET-CT scans reflect tissue metabolism, while the size changes do not serve as a predictor of tumor control.

The SUV ratio is an important factor affecting treatment response, and a decreased SUV ratio after external beam radiotherapy is associated with the degree of tumor necrosis on the histological examination ${ }^{[64]}$. Kim et al ${ }^{[65]}$ indicated that the maximum tumor-to-background ratio calculated by the inferior vena cava $\left(\mathrm{TBR}_{\mathrm{IVCmax}}\right)$ and the uptake-volume product measured by margin thresholds of the $\mathrm{TBR}_{\mathrm{IVC}}$ exhibit higher predictive power for patients after transplantation than other indices. PET-CT was also performed 1 month after interventional treatment to evaluate the therapeutic response. Song et al ${ }^{[66]}$ revealed that ${ }^{18} \mathrm{~F}-\mathrm{FDG}$ PET-CT was efficient in assessing the viability of HCC after transcatheter arterial chemoembolization (TACE) and was superior to CECT in grades I and II and similar in grade III; moreover, nonattenuation-corrected PET data may be helpful for avoiding false-positive results of tracer uptake induced by lipiodol deposition (Figure 1).

TLR only represents the point of the highest metabolic activity of the tumor and does not account for the tumor extent, while metabolic tumor volume (MTV) is a better parameter that represents the extent of abnormally increased FDG uptake by tumor tissue beyond the intensity of FDG uptake in normal tissue. MTV may be an independent prognostic factor for PFS and OS in patients with HCC after TACE ${ }^{[6]}$.

Apart from HCC, ${ }^{18} \mathrm{~F}-\mathrm{FDG}$ PET-CT is also a good predictive tool to assess treatment outcomes of HCC metastasis and for the early identification of treatment failure, especially when additional treatments remain a possibility. One study showed that preradiotherapy SUV ratios and a decline in postradiotherapy SUV ratios were identified as independent predictive factors for bone metastasis, and when combined, these factors predicted outcomes much more effectively than other methods ${ }^{[68]}$.

\section{DUAL-TRACER PET-CT}

Dual-tracer PET-CT with ${ }^{11} \mathrm{C}-\mathrm{ACT}$ and ${ }^{18} \mathrm{~F}$-FDG are biochemical probes of HCC and are complementary to each other. ${ }^{11} \mathrm{C}$-ACT uptake is related to well-differentiated HCC and a less aggressive cancer or a fair prognosis ${ }^{[69]}$. The regenerative nodules are avid for either of the two tracers, and they can be distinguished from $\mathrm{HCC}^{[70]}$. Combining ${ }^{11} \mathrm{C}-\mathrm{CHOL}$ and ${ }^{18} \mathrm{~F}$-FDG PET-CT may also be a valuable option to detect $\mathrm{HCC}$ in the background of chronic liver disease. ${ }^{11} \mathrm{C}-\mathrm{CHOL}$ improves the detection rate for HCC in cases that are negative on conventional ${ }^{18} \mathrm{~F}-\mathrm{FDG}$ PET-CT (Figure 2), and the combination of two tracers can increase the sensitivity of PET-CT to approximately $93 \%{ }^{[71]}$. Dual-tracer PET-CT enhances its capacity to identify lesions and benefits the management of HCC patients.

\section{DYNAMIC BLOOD FLOW AND DUAL-PHASE PET IMAGING}

To obtain a better diagnostic result, additional emerging technologies can be performed, including early dynamic PET imaging and dual-phase PET-CT. Dynamic blood flow PET-CT is centered on the liver, beginning with the injection of ${ }^{18} \mathrm{~F}-\mathrm{FDG}$, to reveal information about both the spatial distribution and temporal kinetics of the tumor, and enables quantitative interpretation of PET data ${ }^{[72]}$.

Time-activity curves are generated from the mean activities for each volume of interest; three blood flow parameters related to the first-pass delivery of FDG are acquired, including peak intensity, time to peak (TTP), and hepatic perfusion index (HPI), which are derived for the HCC lesion and the background liver parenchyma ${ }^{[42]}$. Studies show that TTP and HPI demonstrate significantly better performances than $\mathrm{SUV}_{\max }$ for the discrimination between HCC and background liver tissue, and HPI represents the percentage of arterial supply of the total blood flow in the liver. Early dynamic ${ }^{18} \mathrm{~F}$-FDG PET-CT generates significantly greater contrast during the arterial phase of imaging and similar contrast during the venous phase compared to $\mathrm{CECT}^{[73]}$.

Of course, a conventional (standard static) PET-CT scan of the torso is routinely performed 60 min after FDG injection. Early dynamic ${ }^{18} \mathrm{~F}-\mathrm{FDG}$ PET-CT allows for the improvement of the detection rate for HCC in cases that are negative for HCC on conventional ${ }^{18} \mathrm{~F}$-FDG PET-CT (Figure 3), and the combination of early dynamic ${ }^{18} \mathrm{~F}-$ FDG PET-CT and conventional PET-CT improves the detection ability for $\mathrm{HCC}^{[74]}$. These results indicate that dynamic PET-CT may serve as an alternative where CECT 

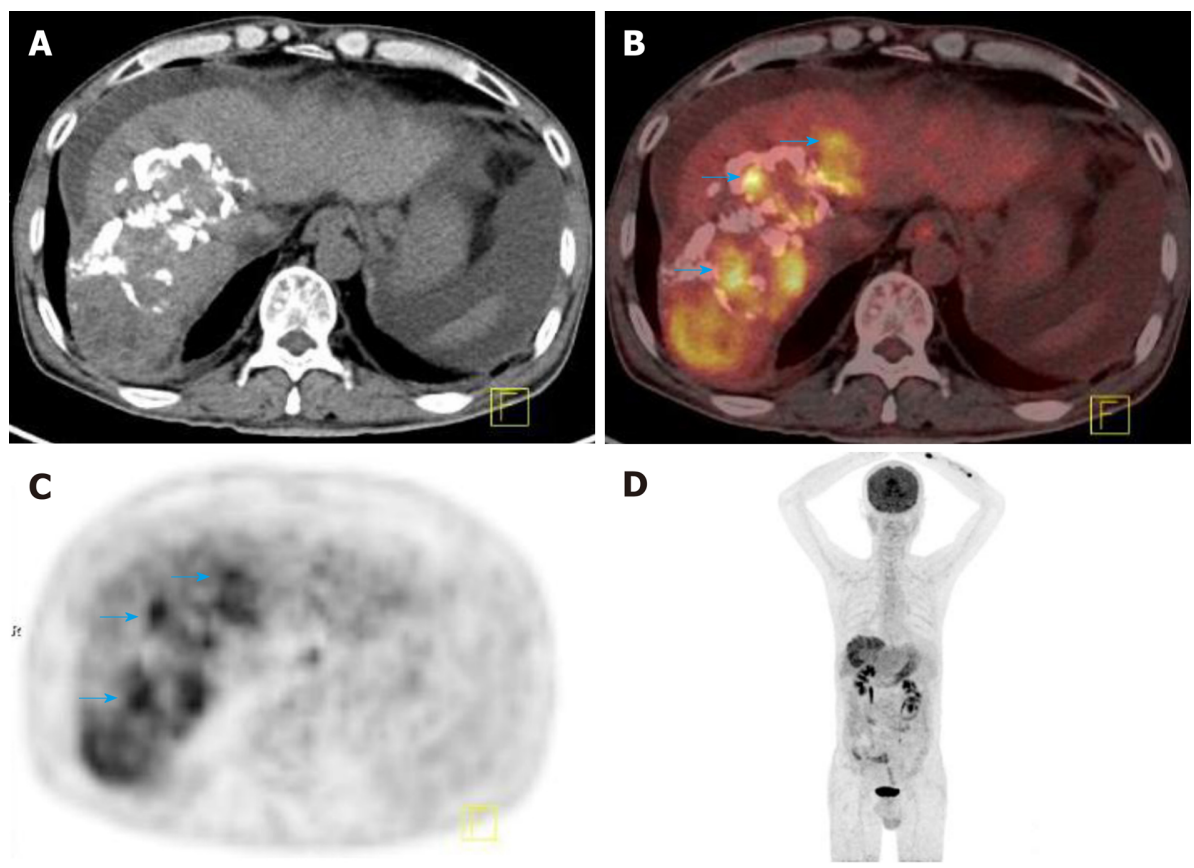

D

Figure 1 2-Deoxy-2-( $\left.{ }^{18} \mathrm{~F}\right)$ fluoro-D-glucose positron-emission tomography-computed tomography detected tumor recurrence after intervention therapy in a 58-year-old male patient with hepatocellular carcinoma. A: Cross-sectional computed tomography (CT) image showing a large sheet of lipiodol deposition in the right lobe of live after HCC intervention therapy; B: Cross-sectional positron-emission tomography (PET-CT) fusion image showing increased ${ }^{18} \mathrm{~F}-\mathrm{FDG}$ uptake in and around the area of lipiodol deposition (blue arrow); the size of the lesion was $5.8 \times$ $13.3 \mathrm{~cm}$; C: Cross-sectional PET image showing increased ${ }^{18} \mathrm{~F}-\mathrm{FDG}$ uptake in the right lobe of the liver; D: Maximum intensity projection image showing increased ${ }^{18} \mathrm{~F}$-FDG uptake in the right lobe of the liver. ${ }^{18} \mathrm{~F}$-FDG: 2-deoxy-2$\left({ }^{18} \mathrm{~F}\right)$ fluoro-D-glucose; CT: Computed tomography; PET: Positron-emission tomography.

or other conventional contrast-enhanced modalities are contraindicated or unavailable. However, early dynamic ${ }^{18} \mathrm{~F}$-FDG PET-CT shows perfusion parameters, and ${ }^{18} \mathrm{~F}-\mathrm{FDG}$ can be absorbed into cells and become involved in intracellular metabolism at the same time ${ }^{[74]}$; therefore, more precise algorithms are needed to separate these parameters from those necessary for image analyses. In addition, formal and prospective clinical studies with a larger number of subjects are needed to explore the value of early dynamic ${ }^{18} \mathrm{~F}-\mathrm{FDG}$ PET-CT in HCC diagnosis.

Dual-phase PET begins with whole-body scanning $60 \mathrm{~min}$ after the injection of ${ }^{18} \mathrm{~F}$ FDG, and delayed scanning begins approximately $2 \mathrm{~h}$ after ${ }^{18} \mathrm{~F}-\mathrm{FDG}$ injection. The tumor may be more clearly visualized by delayed PET-CT imaging of ${ }^{18} \mathrm{~F}-\mathrm{FDG}$, and the uptake may be higher, thus supporting the diagnosis of $\mathrm{HCC}^{[75]}$. Dual-phase imaging of ${ }^{11} \mathrm{C}$-ACT PET acquires early scan immediately after tracer administration and conventional scan in 11-18 min, and it seems to be an available method for the differential diagnosis of focal nodular hyperplasia (FNH) and small hemangioma from malignant lesions ${ }^{[7,77]}$. Both $\mathrm{FNH}$ and small hemangioma are hypervascularized lesions and exhibit positive tracer uptake ratios in early-phase imaging, followed by an immediate decline in the late phase ${ }^{[76]}$. However, well-differentiated HCC demonstrates an increasing tracer uptake over time. Furthermore, compared to CT, MRI, or ultrasound, ${ }^{11} \mathrm{C}$-ACT PET images are not easy to acquire because ${ }^{11} \mathrm{C}$ has a short half-life (20 min), which limits its utility in clinical work.

\section{IMMUNO-PET}

To date, immuno-PET has emerged as a targeted molecular imaging method that represents a promising approach for diagnosing HCC. Glypican-3 (GPC3) is a cell surface protein that is highly expressed in HCC, melanoma, and clear cell carcinoma of the ovary. GPC3 has been proposed as an immunohistochemistry marker to differentiate HCC from benign hepatocyte nodules ${ }^{[78]}$.

${ }^{89} \mathrm{Zr}$ possesses a better half-life $(78.4 \mathrm{~h})$ than other radiotracers and performs well, especially when conjugated with monoclonal antibodies (mAbs). The ${ }^{89} \mathrm{Zr}$-conjugated $\mathrm{mAb}$ against GPC3 ${ }^{89} \mathrm{Zr}$-aGPC3) demonstrates antibody-dependent and antigenspecific tumor binding; the aGPC3 protein was created using the human GPC3 

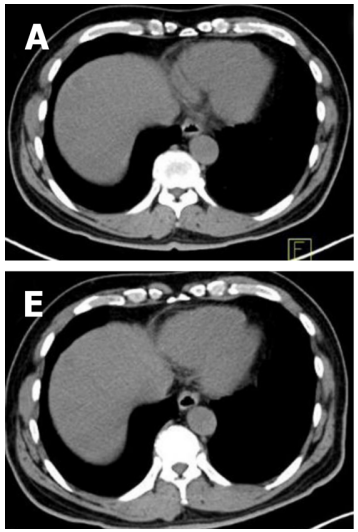

B

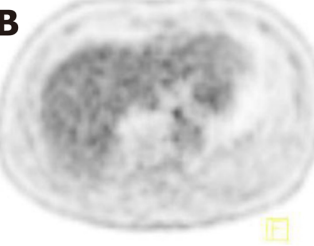

$\mathbf{F}$

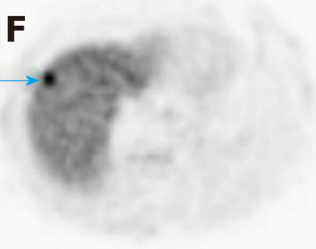

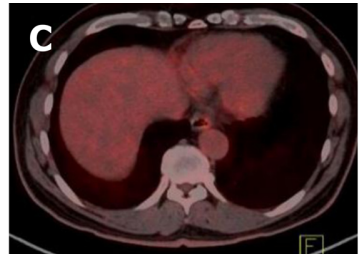

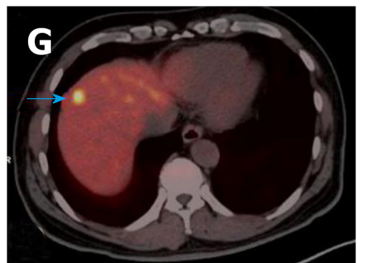

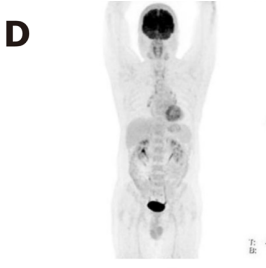

sto

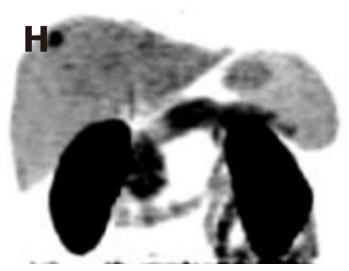

Figure $2{ }^{11} \mathrm{C}$-choline positron-emission tomography-computed tomography detected a tumor that was missed on conventional 2-deoxy-2-( $\left.{ }^{18} \mathrm{~F}\right)$ fluoro-Dglucose positron-emission tomography-computed tomography in a 58-year-old patient with hepatocellular carcinoma. A-D: 2-deoxy-2-( $\left.{ }^{18} \mathrm{~F}\right)$ fluoro-D-glucose positron-emission tomography-computed tomography $\left({ }^{18} \mathrm{~F}\right.$-FDG PET-CT) showed that there was no increased ${ }^{18} \mathrm{~F}$-FDG uptake in the liver; $\mathrm{E}-\mathrm{H}:{ }^{11} \mathrm{C}$-choline $\left({ }^{11} \mathrm{C}\right.$ $\mathrm{CHOL}$ ) PET-CT showed focal increased ${ }^{11} \mathrm{C}-\mathrm{CHOL}$ uptake in the upper segment of the anterior lobe of the liver, and the size of the lesion was $1.2 \times 1.3 \mathrm{~cm}$ (blue arrow in $\mathrm{F}$ and G). Pathological examination confirmed well-differentiated hepatocellular carcinoma. ${ }^{18} \mathrm{~F}$-FDG: 2-deoxy-2-( $\left({ }^{18} \mathrm{~F}\right)$ fluoro-D-glucose; CT: Computed tomography; PET: Positron-emission tomography; ${ }^{11} \mathrm{C}-\mathrm{CHOL}:{ }^{11} \mathrm{C}$-choline.

protein and demonstrated high-affinity binding. ${ }^{89} \mathrm{Zr}$-aGPC3 PET has shown a great capacity for identifying primary liver malignancies, even smaller lesions $(<1 \mathrm{~mm})$, and has demonstrated the capacity to overcome background liver activity ${ }^{[79]}$.

However, mAbs have long half-lives in the blood, leading to suboptimal imaging pharmacokinetics, poor tumor penetration, and increased immunogenicity due to their relatively large size and intact Fc regions. Smaller targeting moieties, such as $\mathrm{F}\left(\mathrm{ab}^{\prime}\right) 2$ fragments, have emerged as an alternative to mAbs. The half-life of ${ }^{89} \mathrm{Zr}$ aGPC3-F $\left(a b^{\prime}\right) 2$ in the blood is approximately $11 \mathrm{~h}$ and enables clear tumor visualization on PET $4 \mathrm{~h}$ after administration and has an excellent signal-to-noise ratio at an early time point ${ }^{[80]}$.

Yang et al ${ }^{[81]}$ synthesized a new PET probe, ${ }^{89} \mathrm{Zr}-\mathrm{DFO}-1 \mathrm{G} 12$, by bioconjugating and radiolabeling anti-GPC3 mAbs (clone $1 \mathrm{G} 12$ ) with ${ }^{89} \mathrm{Zr}$; this probe can be specifically taken up only by GPC3-expressing cells and achieved a high TLR. ${ }^{89} \mathrm{Zr-DFO}-1 \mathrm{G} 12$ detected all GPC3-positive orthotopic HCC xenografts regardless of the level of GPC3 expression, highlighting its clinical value in the diagnosis of all GPC3-expressing HCC.

Another attractive molecular target is CD146, which is overexpressed in multiple cancers and associates with a high histological grade in HCC, but not in normal liver tissue. YY146 is an anti-CD146 mAb; when conjugated, the zwitterionic near-infrared fluorescence (NIRF) dye ZW800-1 and the chelator deferoxamine (Df) enable the labeling of Df-YY146-ZW800 with ${ }^{89} \mathrm{Zr}$ and its subsequent detection with PET and NIRF imaging ${ }^{[82]}{ }^{89} \mathrm{Zr}$-Df-YY146-ZW800 showed excellent properties as a dualmodality imaging agent and exhibited good stability.

The dual-modality imaging capacity not only provides diagnostic information but also may guide surgical resection. All radiotracers for immuno-PET benefit from the long half-life of ${ }^{89} \mathrm{Zr}$; hence, these radiotracers showed better properties for PET imaging. In addition, GPC3 is proposed to be an immunohistochemistry marker that can differentiate HCC from benign hepatocyte nodules ${ }^{[79]}$. However, most studies regarding immuno-PET were performed in animals, and further studies are needed to transfer this technique to clinical use.

\section{PET-MRI}

Combined PET and MRI utilize the advantages of MRI, including increased soft tissue contrast, multiple sequences, lack of ionizing radiation exposure, and use of MRIspecific contrast agents ${ }^{[83]}$. Diffusion-weighted imaging is widely used in tumor evaluation, and the apparent diffusion coefficient can quantify the Brownian motion of water molecules in tissue, which changes during a pathophysiological state. Kong et $a{ }^{[84]}$ indicated that there may exist a negative correlation between increased FDG accumulation and water diffusion in hepatic tumors. PET-MRI is available in HCC staging and follow-up after treatment ${ }^{[85]}$.

Although PET-MRI is promising in many aspects, PET-MRI systems are still relatively rare, and there are several hurdles that prevent its clinical application. 

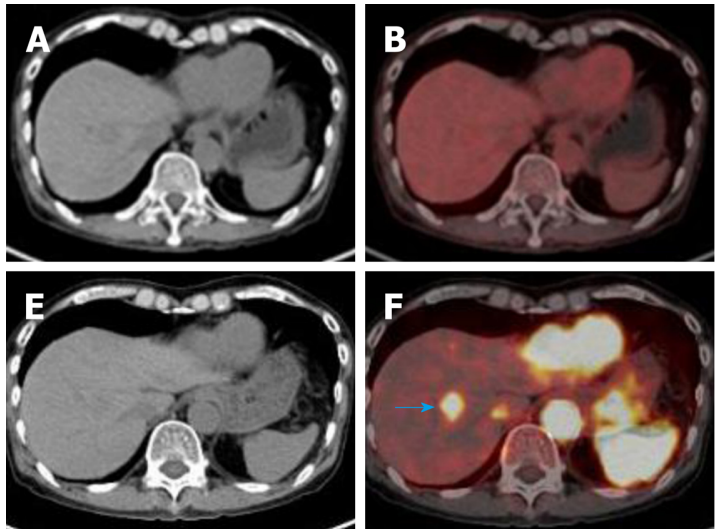
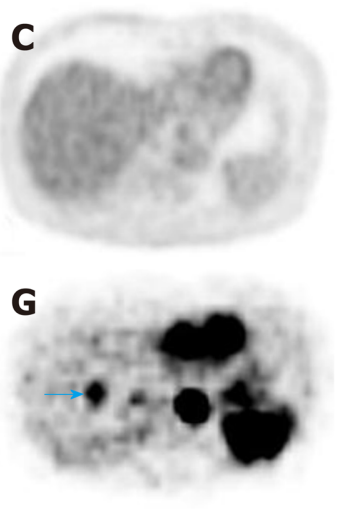

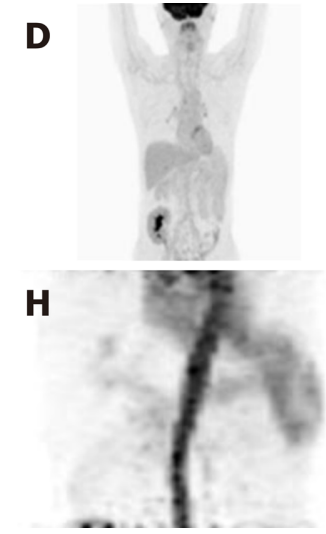

Figure 3 Early dynamic 2-deoxy-2-( $\left.{ }^{18} \mathrm{~F}\right)$ fluoro-D-glucose positron-emission tomography-computed tomography detected a tumor that was missed on conventional 2-deoxy-2-( $\left.{ }^{18} \mathrm{~F}\right)$ fluoro-D-glucose positron-emission tomography-computed tomography in a 64-year-old patient with hepatocellular carcinoma. A-D: 2-deoxy-2-( $\left({ }^{18} \mathrm{~F}\right)$ fluoro-D-glucose positron-emission tomography-computed tomography $\left({ }^{18} \mathrm{~F}\right.$-FDG PET-CT) showed that there was no increased ${ }^{18} \mathrm{~F}$-FDG uptake in the lesion on conventional ${ }^{18} \mathrm{~F}$-FDG PET-CT; E-H: Early dynamic ${ }^{18} \mathrm{~F}$-FDG PET-CT showed focal ${ }^{18} \mathrm{~F}$-FDG hyperperfusion in the upper segment of the anterior lobe of the liver, and the size of the lesion was $1.7 \times 1.9 \mathrm{~cm}$ (blue arrow in $\mathrm{F}$ and $\mathrm{G}) .{ }^{18} \mathrm{~F}-\mathrm{FDG}$ : 2-deoxy-2-( $\left.{ }^{18} \mathrm{~F}\right)$ fluoro-D-glucose; CT: Computed tomography; PET: Positronemission tomography.

Interpretation of PET-MRI requires technician knowledge on both nuclear medicine and MRI, and the examination may take more time. On the other hand, PET-MRI has limited evaluation of pulmonary parenchyma, and patients with metal implants in their bodies cannot undergo MRI. Further studies of PET-MRI utility in clinical applications are needed ${ }^{[83]}$.

\section{CONCLUSION}

Although ${ }^{18} \mathrm{~F}$-FDG PET-CT has emerged as an important noninvasive diagnostic tool in HCC, especially in staging and detecting metastatic lesions, the low sensitivity of ${ }^{18}$ F-FDG PET-CT limits its clinical use, especially for routine surveillance ${ }^{[86]}$. To improve the sensitivity of PET-CT for HCC diagnosis, many new techniques have been carried out, and several methods have been applied. The advent of novel radiotracers and dual-tracer PET-CT increases the sensitivity and enables the visualization of other metabolic processes apart from glucose metabolism. The new modalities require technical expertise and on-site cyclotron facilities; in addition, these radiotracers are expensive and inconvenient for patients ${ }^{[87]}$. Dynamic or dual-phase PET imaging is an alternative modality when other CE modalities cannot be utilized; dual-phase PET imaging provides multiple parameters for quantitative analysis and reflects the blood perfusion in detail. Although false-positive findings might sometimes occur in dynamic PET imaging, it has certain value in diagnosis and differential diagnosis ${ }^{[73]}$.

Radiotracer synthesis and targeted molecular imaging modalities, such as immunoPET, have already become the focus of current research, and their diagnostic capacity for smaller HCC lesions is encouraging. However, most research about radiotracers and immuno-PET is performed on experimental animals, and immuno-PET also shows the overexpression of molecular targets in many non-liver malignancies ${ }^{[79,88]}$. Further evaluation of their immune reactivity is needed, and clinical translation requires more evidence. Additionally, a useful surrogate marker of MVI in small HCC has not yet been established ${ }^{[6]]}$. It is imperative to develop new molecular targets and new probes that can specifically bind to each other. The development of new probes will not only improve diagnostic sensitivity and specificity but also be adapted for the targeted delivery of therapeutic agents ${ }^{[1]}$.

\section{ACKNOWLEDGEMENTS}

We thank our colleagues at the PET-CT Center of the First People's Hospital of Yunnan Province for searching the literature and offering valuable comments.

\section{REFERENCES}


1 Ferlay J, Soerjomataram I, Dikshit R, Eser S, Mathers C, Rebelo M, Parkin DM, Forman D, Bray F. Cancer incidence and mortality worldwide: Sources, methods and major patterns in GLOBOCAN 2012. Int J Cancer 2015; 136: E359-E386 [PMID: 25220842 DOI: 10.1002/ijc.29210]

2 Forner A, Llovet JM, Bruix J. Hepatocellular carcinoma. Lancet 2012; 379: 1245-1255 [PMID: 22353262 DOI: 10.1016/S0140-6736(11)61347-0]

3 Li J, Han X, Yu X, Xu Z, Yang G, Liu B, Xiu P. Clinical applications of liquid biopsy as prognostic and predictive biomarkers in hepatocellular carcinoma: Circulating tumor cells and circulating tumor DNA. $J$ Exp Clin Cancer Res 2018; 37: 213 [PMID: 30176913 DOI: 10.1186/s13046-018-0893-1]

$4 \quad$ Kudo M. Diagnostic imaging of hepatocellular carcinoma: Recent progress. Oncology 2011; 81 Suppl 1: 73-85 [PMID: 22212940 DOI: 10.1159/000333265]

5 Gupta M, Gabriel H, Miller FH. Role of Imaging in Surveillance and Diagnosis of Hepatocellular Carcinoma. Gastroenterol Clin North Am 2018; 47: 585-602 [PMID: 30115439 DOI: 10.1016/j.gtc.2018.04.013]

6 An C, Kim DY, Choi JY, Han KH, Roh YH, Kim MJ. Noncontrast magnetic resonance imaging versus ultrasonography for hepatocellular carcinoma surveillance (MIRACLE-HCC): Study protocol for a prospective randomized trial. BMC Cancer 2018; 18: 915 [PMID: 30249190 DOI: 10.1186/s12885-018-4827-2]

7 Hennedige T, Venkatesh SK. Advances in computed tomography and magnetic resonance imaging of hepatocellular carcinoma. World J Gastroenterol 2016; 22: 205-220 [PMID: 26755871 DOI: 10.3748/wjg.v22.11.205]

8 Liao X, Wei J, Li Y, Zhong J, Liu Z, Liao S, Li Q, Wei C. 18F-FDG PET with or without CT in the diagnosis of extrahepatic metastases or local residual/recurrent hepatocellular carcinoma. Medicine (Baltimore) 2018; 97: e11970 [PMID: 30142825 DOI: 10.1097/MD.0000000000011970]

9 Song JY, Lee YN, Kim YS, Kim SG, Jin SJ, Park JM, Choi GS, Chung JC, Lee MH, Cho YH, Choi MH, Kim DC, Choi HJ, Moon JH, Lee SH, Jeong SW, Jang JY, Kim HS, Kim BS. Predictability of preoperative $18 \mathrm{~F}-\mathrm{FDG}$ PET for histopathological differentiation and early recurrence of primary malignant intrahepatic tumors. Nucl Med Commun 2015; 36: 319-327 [PMID: 25564069 DOI: 10.1097/MNM.0000000000000254]

10 Jiang HY, Chen J, Xia CC, Cao LK, Duan T, Song B. Noninvasive imaging of hepatocellular carcinoma: From diagnosis to prognosis. World J Gastroenterol 2018; 24: 2348-2362 [PMID: 29904242 DOI: 10.3748/wjg.v24.i22.2348]

11 Lee SM, Kim HS, Lee S, Lee JW. Emerging role of 18F-fluorodeoxyglucose positron emission tomography for guiding management of hepatocellular carcinoma. World J Gastroenterol 2019; 25: 12891306 [PMID: 30918424 DOI: 10.3748/wjg.v25.111.1289]

12 Ametamey SM, Honer M, Schubiger PA. Molecular imaging with PET. Chem Rev 2008; 108: 1501-1516 [PMID: 18426240 DOI: 10.1021/cr0782426]

13 Brito AF, Mendes M, Abrantes AM, Tralhão JG, Botelho MF. Positron emission tomography diagnostic imaging in multidrug-resistant hepatocellular carcinoma: Focus on 2-deoxy-2-(18F)Fluoro-D-Glucose. Mol Diagn Ther 2014; 18: 495-504 [PMID: 24852041 DOI: 10.1007/s40291-014-0106-3]

14 Chiotellis A, Muller A, Mu L, Keller C, Schibli R, Krämer SD, Ametamey SM. Synthesis and biological evaluation of (18)F-labeled Fluoroethoxy tryptophan analogues as potential PET tumor imaging agents. Mol Pharm 2014; 11: 3839-3851 [PMID: 24988527 DOI: 10.1021/mp500312t]

15 Krasikova RN, Kuznetsova OF, Fedorova OS, Belokon YN, Maleev VI, Mu L, Ametamey S, Schubiger PA, Friebe M, Berndt M, Koglin N, Mueller A, Graham K, Lehmann L, Dinkelborg LM. 4[18F]fluoroglutamic acid (BAY 85-8050), a new amino acid radiotracer for PET imaging of tumors: Synthesis and in vitro characterization. J Med Chem 2011; 54: 406-410 [PMID: 21128591 DOI: $10.1021 / \mathrm{jm} 101068 \mathrm{q}]$

16 Li Y, Zhang D, Shi Y, Guo Z, Wu X, Ren JL, Zhang X, Wu H. Syntheses and preliminary evaluation of [(18) F]AIF-NOTA-G-TMTP1 for PET imaging of high aggressive hepatocellular carcinoma. Contrast Media Mol Imaging 2016; 11: 262-271 [PMID: 26931574 DOI: 10.1002/cmmi.1688]

17 Kavanaugh G, Williams J, Morris AS, Nickels ML, Walker R, Koglin N, Stephens AW, Washington MK, Geevarghese SK, Liu Q, Ayers D, Shyr Y, Manning HC. Utility of [18F]FSPG PET to Image Hepatocellular Carcinoma: First Clinical Evaluation in a US Population. Mol Imaging Biol 2016; 18: 924934 [PMID: 27677886 DOI: 10.1007/s11307-016-1007-0]

18 He S, Tang G, Hu K, Wang H, Wang S, Huang T, Liang X, Tang X. Radiosynthesis and biological evaluation of 5-(3-[18F]fluoropropyloxy)-L-tryptophan for tumor PET imaging. Nucl Med Biol 2013; 40: 801-807 [PMID: 23791401 DOI: 10.1016/j.nucmedbio.2013.04.013]

19 Sun A, Liu S, Tang X, Nie D, Tang G, Zhang Z, Wen F, Wang X. Simple and rapid radiosynthesis of N18F-labeled glutamic acid as a hepatocellular carcinoma PET tracer. Nucl Med Biol 2017; 49: 38-43 [PMID: 28301817 DOI: 10.1016/j.nucmedbio.2017.02.003]

20 Hu K, Du K, Tang G, Yao S, Wang H, Liang X, Yao B, Huang T, Zang L. Radiosynthesis and biological evaluation of $\mathrm{N}-[18 \mathrm{~F}]$ labeled glutamic acid as a tumor metabolic imaging tracer. PLoS One 2014; 9 : e93262 [PMID: 24681642 DOI: 10.1371/journal.pone.0093262]

21 Bieze M, Klümpen HJ, Verheij J, Beuers U, Phoa SS, van Gulik TM, Bennink RJ. Diagnostic accuracy of (18) F-methylcholine positron emission tomography/computed tomography for intra- and extrahepatic hepatocellular carcinoma. Hepatology 2014; 59: 996-1006 [PMID: 24123111 DOI: 10.1002/hep.26781]

22 Talbot JN, Fartoux L, Balogova S, Nataf V, Kerrou K, Gutman F, Huchet V, Ancel D, Grange JD, Rosmorduc O. Detection of hepatocellular carcinoma with PET/CT: A prospective comparison of $18 \mathrm{~F}-$ fluorocholine and 18F-FDG in patients with cirrhosis or chronic liver disease. J Nucl Med 2010; 51: 16991706 [PMID: 20956466 DOI: 10.2967/jnumed.110.075507]

23 Menzel MI, Farrell EV, Janich MA, Khegai O, Wiesinger F, Nekolla S, Otto AM, Haase A, Schulte RF, Schwaiger M. Multimodal assessment of in vivo metabolism with hyperpolarized [1-13C]MR spectroscopy and 18F-FDG PET imaging in hepatocellular carcinoma tumor-bearing rats. J Nucl Med 2013; 54: 1113-1119 [PMID: 23596002 DOI: 10.2967/jnumed.112.110825]

24 Song WS, Nielson BR, Banks KP, Bradley YC. Normal organ standard uptake values in carbon-11 acetate PET imaging. Nucl Med Commun 2009; 30: 462-465 [PMID: 19357549 DOI: 10.1097/MNM.0b013e32832aa7ce]

25 Park JW, Kim JH, Kim SK, Kang KW, Park KW, Choi JI, Lee WJ, Kim CM, Nam BH. A prospective evaluation of 18F-FDG and 11C-acetate PET/CT for detection of primary and metastatic hepatocellular carcinoma. J Nucl Med 2008; 49: 1912-1921 [PMID: 18997056 DOI: 10.2967/jnumed.108.055087] Li L, Che L, Wang C, Blecha JE, Li X, VanBrocklin HF, Calvisi DF, Puchowicz M, Chen X, Seo Y. 
[(11)C]acetate PET Imaging is not Always Associated with Increased Lipogenesis in Hepatocellular Carcinoma in Mice. Mol Imaging Biol 2016; 18: 360-367 [PMID: 26567114 DOI: 10.1007/s11307-015-0915-8]

27 Hwang KH, Choi DJ, Lee SY, Lee MK, Choe W. Evaluation of patients with hepatocellular carcinomas using [(11)C]acetate and [(18)F]FDG PET/CT: A preliminary study. Appl Radiat Isot 2009; 67: 1195-1198 [PMID: 19342249 DOI: 10.1016/j.apradiso.2009.02.011]

28 Kolthammer JA, Corn DJ, Tenley N, Wu C, Tian H, Wang Y, Lee Z. PET imaging of hepatocellular carcinoma with 18F-fluoroethylcholine and 11C-choline. Eur J Nucl Med Mol Imaging 2011; 38: 12481256 [PMID: 21344223 DOI: 10.1007/s00259-011-1743-y]

29 Jadvar H. Hepatocellular carcinoma and gastroenteropancreatic neuroendocrine tumors: Potential role of other positron emission tomography radiotracers. Semin Nucl Med 2012; 42: 247-254 [PMID: 22681673 DOI: 10.1053/j.semnuclmed.2012.02.001]

30 Hoffend J, Mier W, Schuhmacher J, Schmidt K, Dimitrakopoulou-Strauss A, Strauss LG, Eisenhut M, Kinscherf R, Haberkorn U. Gallium-68-DOTA-albumin as a PET blood-pool marker: Experimental evaluation in vivo. Nucl Med Biol 2005; 32: 287-292 [PMID: 15820764 DOI:

10.1016/j.nucmedbio.2005.01.002]

31 Haubner R, Finkenstedt A, Stegmayr A, Rangger C, Decristoforo C, Zoller H, Virgolini IJ [(68)Ga]NODAGA-RGD - Metabolic stability, biodistribution, and dosimetry data from patients with hepatocellular carcinoma and liver cirrhosis. Eur J Nucl Med Mol Imaging 2016; 43: 2005-2013 [PMID: 27164900 DOI: 10.1007/s00259-016-3396-3]

32 Gao Y, Wang Z, Ma X, Ma W, Zhao M, Fu T, Li G, Wang S, Wang Z, Yang W, Kang F, Wang J. The uptake exploration of $68 \mathrm{Ga}$-labeled NGR in well-differentiated hepatocellular carcinoma xenografts: Indication for the new clinical translational of a tracer based on NGR. Oncol Rep 2017; 38: 2859-2866 [PMID: 28901442 DOI: 10.3892/or.2017.5933]

33 Wachsmann J, Peng F. Molecular imaging and therapy targeting copper metabolism in hepatocellular carcinoma. World J Gastroenterol 2016; 22: 221-231 [PMID: 26755872 DOI: 10.3748/wjg.v22.i1.221]

34 Kornberg A, Küpper B, Tannapfel A, Büchler P, Krause B, Witt U, Gottschild D, Friess H. Patients with non-[18 F]fludeoxyglucose-avid advanced hepatocellular carcinoma on clinical staging may achieve longterm recurrence-free survival after liver transplantation. Liver Transpl 2012; 18: 53-61 [PMID: 21850692 DOI: $10.1002 / 1 t .22416]$

35 Hiraoka A, Hirooka M, Ochi H, Koizumi Y, Shimizu Y, Shiraishi A, Yamago H, Tanihira T, Miyata H, Ninomiya T, Kawasaki H, Ishimaru Y, Sogabe I, Inoue T, Abe M, Hiasa Y, Matsuura B, Onji M, Michitaka K. Importance of screening for synchronous malignant neoplasms in patients with hepatocellular carcinoma: Impact of FDG PET/CT. Liver Int 2013; 33: 1085-1091 [PMID: 23601196 DOI: 10.1111/liv.12161]

36 Kawamura E, Shiomi S, Kotani K, Kawabe J, Hagihara A, Fujii H, Uchida-Kobayashi S, Iwai S, Morikawa H, Enomoto M, Murakami Y, Tamori A, Kawada N. Positioning of 18F-fluorodeoxyglucosepositron emission tomography imaging in the management algorithm of hepatocellular carcinoma. $J$ Gastroenterol Hepatol 2014; 29: 1722-1727 [PMID: 24730671 DOI: 10.1111/jgh.12611]

37 European Association for the Study of the Liver. EASL Clinical Practice Guidelines: Management of hepatocellular carcinoma. J Hepatol 2018; 69: 182-236 [PMID: 29628281 DOI: 10.1016/j.jhep.2018.03.019]

38 Li YC, Yang CS, Zhou WL, Li HS, Han YJ, Wang QS, Wu HB. Low glucose metabolism in hepatocellular carcinoma with GPC3 expression. World J Gastroenterol 2018; 24: 494-503 [PMID: 29398870 DOI: 10.3748/wjg.v24.i4.494]

39 Wu HB, Wang QS, Li BY, Li HS, Zhou WL, Wang QY. F-18 FDG in conjunction with 11C-choline PET/CT in the diagnosis of hepatocellular carcinoma. Clin Nucl Med 2011; 36: 1092-1097 [PMID: 22064078 DOI: 10.1097/RLU.0b013e3182335df4]

40 Seo S, Hatano E, Higashi T, Nakajima A, Nakamoto Y, Tada M, Tamaki N, Iwaisako K, Kitamura K, Ikai I, Uemoto S. P-glycoprotein expression affects $18 \mathrm{~F}$-fluorodeoxyglucose accumulation in hepatocellular carcinoma in vivo and in vitro. Int J Oncol 2009; 34: 1303-1312 [PMID: 19360342 DOI: 10.3892/ijo_00000257]

41 Anis M, Irshad A. Imaging of hepatocellular carcinoma: Practical guide to differential diagnosis. Clin Liver Dis 2011; 15: 335-352, vii-vix [PMID: 21689617 DOI: 10.1016/j.cld.2011.03.014]

42 Bernstine H, Braun M, Yefremov N, Lamash Y, Carmi R, Stern D, Steinmetz A, Sosna J, Groshar D. FDG PET/CT early dynamic blood flow and late standardized uptake value determination in hepatocellular carcinoma. Radiology 2011; 260: 503-510 [PMID: 21555347 DOI: 10.1148/radiol.11102350]

43 Klasser GD, Echandi L, Shannon M. Hepatocellular carcinoma metastasis to the condyle: A case report and review of the literature. $J$ Am Dent Assoc 2014; 145: 1063-1067 [PMID: 25270706 DOI: 10.14219/jada.2014.70]

44 Cho Y, Lee DH, Lee YB, Lee M, Yoo JJ, Choi WM, Cho YY, Paeng JC, Kang KW, Chung JK, Yu SJ, Lee JH, Yoon JH, Lee HS, Kim YJ. Does 18F-FDG positron emission tomography-computed tomography have a role in initial staging of hepatocellular carcinoma? PLoS One 2014; 9: e105679 [PMID: 25153834 DOI: 10.1371/journal.pone.0105679]

45 Xia F, Wu L, Lau WY, Li G, Huan H, Qian C, Ma K, Bie P. Positive lymph node metastasis has a marked impact on the long-term survival of patients with hepatocellular carcinoma with extrahepatic metastasis. PLoS One 2014; 9: e95889 [PMID: 24760012 DOI: 10.1371/journal.pone.0095889]

46 Lin Y, Jeng LB, Wang HY, Tsai SC, Lin WY, Kao CH. Clinical Value of 18F-FDG PET/CT in Detecting Adrenal Metastasis in Patients with Hepatocellular Carcinoma. Technol Cancer Res Treat 2015; 14: 593599 [PMID: 24945368 DOI: 10.7785/tcrt.2012.500438]

47 Sung TY, Lee SR, Lee JH, Lee YM, Lee AL, Hwang DW, Yoon JH, Gong G, Hong SJ, Park KM. Hepatocellular carcinoma eats medullary thyroid carcinoma, a case of tumor-in-tumor metastasis. Endocr $J$ 2011; 58: 801-805 [PMID: 21757828 DOI: 10.1507/endocrj.ej11-0052]

48 Pan JH, Dong MJ, Ouyang XB. A hepatoid adenocarcinoma of the stomach with liver metastasis mimicking hepatocellular carcinoma detected by F-18 FDG PET/CT imaging. Clin Nucl Med 2011; 36 1137-1139 [PMID: 22064094 DOI: 10.1097/RLU.0b013e3182335ef9]

49 Lee JH, Lee KG, Park HK, Song SY, Kim JY, Kim YH, Choi YY, Jang KS, Park MH. Inflammatory pseudotumor of the kidney mimicking malignancy on 18F-FDG PET/CT in a patient with diabetes and hepatocellular carcinoma. Clin Nucl Med 2012; 37: 699-701 [PMID: 22691519 DOI: 10.1097/RLU.0b013e3182443e4d]

50 Dong A, Zhong X, Wang Y. Pedunculated Hepatocellular Carcinoma Mimicking Right Adrenal Tumor on 
FDG PET/CT. Clin Nucl Med 2018; 43: e242-e244 [PMID: 29659392 DOI:

10.1097/RLU.0000000000002096]

51 Tsurusaki M, Okada M, Kuroda H, Matsuki M, Ishii K, Murakami T. Clinical application of 18Ffluorodeoxyglucose positron emission tomography for assessment and evaluation after therapy for malignant hepatic tumor. $J$ Gastroenterol 2014; 49: 46-56 [PMID: 23525980 DOI: 10.1007/s00535-013-0790-5]

52 Agarwal KK, Shah D, Shah N, Mayank M. Differentiation of Malignant Thrombus From Bland Thrombus of the Portal Vein in Patient With Hepatocellular Carcinoma on 18F-FDG PET CT. Clin Nucl Med 2017; 42: e472-e474 [PMID: 28922192 DOI: 10.1097/RLU.0000000000001840]

53 Hu Y, Liu Y, Shi H. Castleman disease in the hilum liver mimicking the lymph node metastasis of hepatocellular carcinoma on 18F-FDG PET/CT: A case report. Medicine (Baltimore) 2018; 97: e9939 [PMID: 29561464 DOI: 10.1097/MD.0000000000009939]

54 Jiang L, Tan H, Panje CM, Yu H, Xiu Y, Shi H. Role of 18F-FDG PET/CT Imaging in Intrahepatic Cholangiocarcinoma. Clin Nucl Med 2016; 41: 1-7 [PMID: 26402131 DOI: 10.1097/RLU.0000000000000998]

55 Takada Y, Kaido T, Shirabe K, Nagano H, Egawa H, Sugawara Y, Taketomi A, Takahara T, Wakabayashi G, Nakanishi C, Kawagishi N, Kenjo A, Gotoh M, Toyoki Y, Hakamada K, Ohtsuka M, Akamatsu N, Kokudo N, Takeda K, Endo I, Takamura H, Okajima H, Wada H, Kubo S, Kuramitsu K, Ku Y, Ishiyama K, Ohdan H, Ito E, Maehara Y, Honda M, Inomata Y, Furukawa H, Uemoto S, Yamaue H, Miyazaki M, Takada T; LTx-PET study group of the Japanese Society of Hepato-Biliary-Pancreatic Surgery and the Japanese Liver Transplantation Society. Significance of preoperative fluorodeoxyglucosepositron emission tomography in prediction of tumor recurrence after liver transplantation for hepatocellular carcinoma patients: A Japanese multicenter study. J Hepatobiliary Pancreat Sci 2017; 24: 49-57 [PMID: 27806426 DOI: 10.1002/jhbp.412]

56 Sacks A, Peller PJ, Surasi DS, Chatburn L, Mercier G, Subramaniam RM. Value of PET/CT in the management of primary hepatobiliary tumors, part 2. AJR Am J Roentgenol 2011; 197: W260-W265 [PMID: 21785051 DOI: 10.2214/AJR.11.6995]

57 Na SJ, Oh JK, Hyun SH, Lee JW, Hong IK, Song BI, Kim TS, Eo JS, Lee SW, Yoo IR, Chung YA, Yun M. 18F-FDG PET/CT Can Predict Survival of Advanced Hepatocellular Carcinoma Patients: A Multicenter Retrospective Cohort Study. J Nucl Med 2017; 58: 730-736 [PMID: 27789714 DOI: 10.2967/jnumed.116.182022]

58 Sposito C, Di Sandro S, Brunero F, Buscemi V, Battiston C, Lauterio A, Bongini M, De Carlis L, Mazzaferro V. Development of a prognostic scoring system for resectable hepatocellular carcinoma. World J Gastroenterol 2016; 22: 8194-8202 [PMID: 27688661 DOI: 10.3748/wjg.v22.i36.8194]

59 Ahn SY, Lee JM, Joo I, Lee ES, Lee SJ, Cheon GJ, Han JK, Choi BI. Prediction of microvascular invasion of hepatocellular carcinoma using gadoxetic acid-enhanced MR and (18)F-FDG PET/CT. Abdom Imaging 2015; 40: 843-851 [PMID: 25253426 DOI: 10.1007/s00261-014-0256-0]

60 Ünal E, İdilman İS, Akata D, Özmen MN, Karçaaltıncaba M. Microvascular invasion in hepatocellular carcinoma. Diagn Interv Radiol 2016; 22: 125-132 [PMID: 26782155 DOI: 10.5152/dir.2015.15125]

61 Kobayashi T, Aikata H, Honda F, Nakano N, Nakamura Y, Hatooka M, Morio K, Morio R, Fukuhara T, Masaki K, Nagaoki Y, Kawaoka T, Tsuge M, Hiramatsu A, Imamura M, Kawakami Y, Ohdan H, Awai K, Chayama K. Preoperative Fluorine 18 Fluorodeoxyglucose Positron Emission Tomography/Computed Tomography for Prediction of Microvascular Invasion in Small Hepatocellular Carcinoma. J Comput Assist Tomogr 2016; 40: 524-530 [PMID: 26966955 DOI: 10.1097/RCT.0000000000000405]

62 Wang XY, Chen D, Zhang XS, Chen ZF, Hu AB. Value of ${ }^{1}$ F-FDG-PET/CT in the detection of recurrent hepatocellular carcinoma after hepatectomy or radiofrequency ablation: A comparative study with contrast-enhanced ultrasound. J Dig Dis 2013; 14: 433-438 [PMID: 23615075 DOI: 10.1111/1751-2980.12064]

63 Cascales-Campos PA, Romero PR, Schneider MA, Lopez-Lopez V, Navarro JL, Frutos L, Pons Miñano JA, Paricio PP. Positron emission tomography/computed tomography in patients with hepatocellular carcinoma undergoing liver transplantation. Useful, necessary or irrelevant? Eur J Radiol 2017; 91: 155159 [PMID: 28629563 DOI: 10.1016/j.ejrad.2017.03.013]

64 Kim JW, Seong J, Yun M, Lee IJ, Yoon HI, Cho HJ, Han KH. Usefulness of positron emission tomography with fluorine-18-fluorodeoxyglucose in predicting treatment response in unresectable hepatocellular carcinoma patients treated with external beam radiotherapy. Int J Radiat Oncol Biol Phys 2012; 82: 1172-1178 [PMID: 21570203 DOI: 10.1016/j.ijrobp.2010.11.076]

65 Kim YI, Paeng JC, Cheon GJ, Suh KS, Lee DS, Chung JK, Kang KW. Prediction of Posttransplantation Recurrence of Hepatocellular Carcinoma Using Metabolic and Volumetric Indices of 18F-FDG PET/CT. $J$ Nucl Med 2016; 57: 1045-1051 [PMID: 26985057 DOI: 10.2967/jnumed.115.170076]

66 Song HJ, Cheng JY, Hu SL, Zhang GY, Fu Y, Zhang YJ. Value of 18F-FDG PET/CT in detecting viable tumour and predicting prognosis of hepatocellular carcinoma after TACE. Clin Radiol 2015; 70: 128-137 [PMID: 25459673 DOI: 10.1016/j.crad.2014.09.020]

67 Lee JW, Yun M, Cho A, Han KH, Kim DY, Lee SM, Lee JD. The predictive value of metabolic tumor volume on FDG PET/CT for transarterial chemoembolization and transarterial chemotherapy infusion in hepatocellular carcinoma patients without extrahepatic metastasis. Ann Nucl Med 2015; 29: 400-408 [PMID: 25652647 DOI: 10.1007/s12149-015-0956-8]

68 Choi SH, Chang JS, Jeong YH, Lee Y, Yun M, Seong J. FDG-PET predicts outcomes of treated bone metastasis following palliative radiotherapy in patients with hepatocellular carcinoma. Liver Int 2014; 34 1118-1125 [PMID: 24528941 DOI: 10.1111/liv.12487]

69 Park S, Kim TS, Kang SH, Kim HB, Park JW, Kim SK. 11C-acetate and 18F-fluorodeoxyglucose positron emission tomography/computed tomography dual imaging for the prediction of response and prognosis after transarterial chemoembolization. Medicine (Baltimore) 2018; 97: e12311 [PMID: 30212970 DOI: 10.1097/MD.0000000000012311]

70 Cheung TT, Ho CL, Lo CM, Chen S, Chan SC, Chok KS, Fung JY, Yan Chan AC, Sharr W, Yau T, Poon RT, Fan ST. 11C-acetate and 18F-FDG PET/CT for clinical staging and selection of patients with hepatocellular carcinoma for liver transplantation on the basis of Milan criteria: Surgeon's perspective. $J$ Nucl Med 2013; 54: 192-200 [PMID: 23321459 DOI: 10.2967/jnumed.112.107516]

71 Castilla-Lièvre MA, Franco D, Gervais P, Kuhnast B, Agostini H, Marthey L, Désarnaud S, Helal BO. Diagnostic value of combining ${ }^{11} \mathrm{C}$-choline and ${ }^{\mathrm{F}} \mathrm{F}$-FDG PET/CT in hepatocellular carcinoma. Eur J Nucl Med Mol Imaging 2016; 43: 852-859 [PMID: 26577938 DOI: 10.1007/s00259-015-3241-0]

72 Dutta J, Leahy RM, Li Q. Non-local means denoising of dynamic PET images. PLoS One 2013; 8: 
e81390 [PMID: 24339921 DOI: 10.1371/journal.pone.0081390]

73 Freesmeyer M, Winkens T, Schierz JH. Contrast between hypervascularized liver lesions and hepatic parenchyma: Early dynamic PET versus contrast-enhanced CT. Ann Nucl Med 2014; 28: 664-668 [PMID: 24903245 DOI: 10.1007/s12149-014-0862-5]

74 Wang SB, Wu HB, Wang QS, Zhou WL, Tian Y, Li HS, Ji YH, Lv L. Combined early dynamic (18)FFDG PET/CT and conventional whole-body (18)F-FDG PET/CT provide one-stop imaging for detecting hepatocellular carcinoma. Clin Res Hepatol Gastroenterol 2015; 39: 324-330 [PMID: 25487755 DOI: 10.1016/j.clinre.2014.10.010]

75 Wu B, Zhao Y, Zhang Y, Tan H, Shi H. Does dual-time-point 18F-FDG PET/CT scan add in the diagnosis of hepatocellular carcinoma? Hell J Nucl Med 2017; 20: 79-82 [PMID: 28315913 DOI: 10.1967/s002449910511]

76 Huo L, Dang Y, Lv J, Xing H, Li F. Application of dual phase imaging of 11C-acetate positron emission tomography on differential diagnosis of small hepatic lesions. PLoS One 2014; 9: e96517 [PMID: 24816814 DOI: 10.1371/journal.pone.0096517]

77 Huo L, Wu Z, Zhuang H, Fu Z, Dang Y. Dual time point C-11 acetate PET imaging can potentially distinguish focal nodular hyperplasia from primary hepatocellular carcinoma. Clin Nucl Med 2009; 34: 874-877 [PMID: 20139820 DOI: 10.1097/RLU.0b013e3181bed06e]

78 Ho M, Kim H. Glypican-3: A new target for cancer immunotherapy. Eur J Cancer 2011; 47: 333-338 [PMID: 21112773 DOI: 10.1016/j.ejca.2010.10.024]

79 Sham JG, Kievit FM, Grierson JR, Miyaoka RS, Yeh MM, Zhang M, Yeung RS, Minoshima S, Park JO. Glypican-3-targeted 89Zr PET imaging of hepatocellular carcinoma. J Nucl Med 2014; 55: 799-804 [PMID: 24627434 DOI: 10.2967/jnumed.113.132118]

80 Sham JG, Kievit FM, Grierson JR, Chiarelli PA, Miyaoka RS, Zhang M, Yeung RS, Minoshima S, Park JO. Glypican-3-targeting F(ab')2 for 89Zr PET of hepatocellular carcinoma. J Nucl Med 2014; 55: 20322037 [PMID: 25359880 DOI: $10.2967 /$ jnumed.114.145102]

81 Yang X, Liu H, Sun CK, Natarajan A, Hu X, Wang X, Allegretta M, Guttmann RD, Gambhir SS, Chua MS, Cheng Z, So SK. Imaging of hepatocellular carcinoma patient-derived xenografts using Zr-labeled anti-glypican-3 monoclonal antibody. Biomaterials 2014; 35: 6964-6971 [PMID: 24836949 DOI: 10.1016/j.biomaterials.2014.04.089]

82 Hernandez R, Sun H, England CG, Valdovinos HF, Ehlerding EB, Barnhart TE, Yang Y, Cai W. CD146targeted immunoPET and NIRF Imaging of Hepatocellular Carcinoma with a Dual-Labeled Monoclonal Antibody. Theranostics 2016; 6: 1918-1933 [PMID: 27570560 DOI: 10.7150/thno.15568]

83 Ehman EC, Johnson GB, Villanueva-Meyer JE, Cha S, Leynes AP, Larson PEZ, Hope TA. PET/MRI: Where might it replace PET/CT? J Magn Reson Imaging 2017; 46: 1247-1262 [PMID: 28370695 DOI: 10.1002/jmri.25711]

84 Kong E, Chun KA, Cho IH. Quantitative assessment of simultaneous F-18 FDG PET/MRI in patients with various types of hepatic tumors: Correlation between glucose metabolism and apparent diffusion coefficient. PLoS One 2017; 12: e0180184 [PMID: 28672016 DOI: 10.1371/journal.pone.0180184]

85 Nielsen K, Scheffer HJ, Pieters IC, van Tilborg AA, van Waesberghe JH, Oprea-Lager DE, Meijerink MR, Kazemier G, Hoekstra OS, Schreurs HW, Sietses C, Meijer S, Comans EF, van den Tol PM. The use of PET-MRI in the follow-up after radiofrequency- and microwave ablation of colorectal liver metastases. BMC Med Imaging 2014; 14: 27 [PMID: 25103913 DOI: 10.1186/1471-2342-14-27]

86 Hayakawa N, Nakamoto Y, Nakatani K, Hatano E, Seo S, Higashi T, Saga T, Uemoto S, Togashi K. Clinical utility and limitations of FDG PET in detecting recurrent hepatocellular carcinoma in postoperative patients. Int J Clin Oncol 2014; 19: 1020-1028 [PMID: 24366329 DOI: 10.1007/s10147-013-0653-3]

87 Dubash SR, Idowu OA, Sharma R. The emerging role of positron emission tomography in hepatocellular carcinoma. Hepat Oncol 2015; 2: 191-200 [PMID: 30190998 DOI: 10.2217/hep.15.6]

88 Marquez BV, Zheleznyak A, Lapi SE. Glypican-3-targeted 89Zr PET imaging of hepatocellular carcinoma: Where antibody imaging dares to tread. J Nucl Med 2014; 55: $708-709$ [PMID: 24665087 DOI: 10.2967/jnumed.113.136234]

89 Lin CY, Chen JH, Liang JA, Lin CC, Jeng LB, Kao CH. 18F-FDG PET or PET/CT for detecting extrahepatic metastases or recurrent hepatocellular carcinoma: A systematic review and meta-analysis. Eur J Radiol 2012; 81: 2417-2422 [PMID: 21899970 DOI: 10.1016/j.ejrad.2011.08.004] 


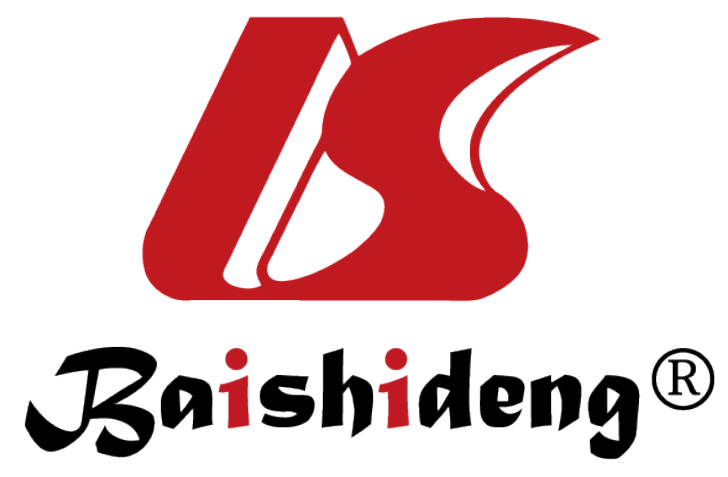

Published By Baishideng Publishing Group Inc

7041 Koll Center Parkway, Suite 160, Pleasanton, CA 94566, USA

Telephone: +1-925-2238242

Fax: +1-925-2238243

E-mail: bpgoffice@wjgnet.com

Help Desk:http://www.f6publishing.com/helpdesk

http://www.wjgnet.com

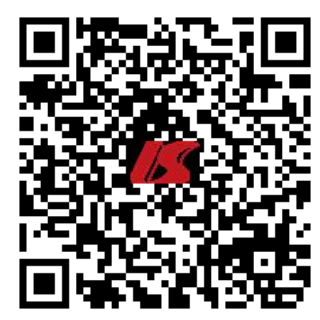

